\title{
基于超效率 DEA 的中国工业与服务业的效率及其协调度评价
}

Efficiency Evaluation and Coordination Degree of Chinese Industry and Service Industry Based on Super Efficiency DEA

王建府 顾凯凯 班顺 赵水晶

Jianfu Wang Kaikai Gu Shun Ban Shuijing Zhao

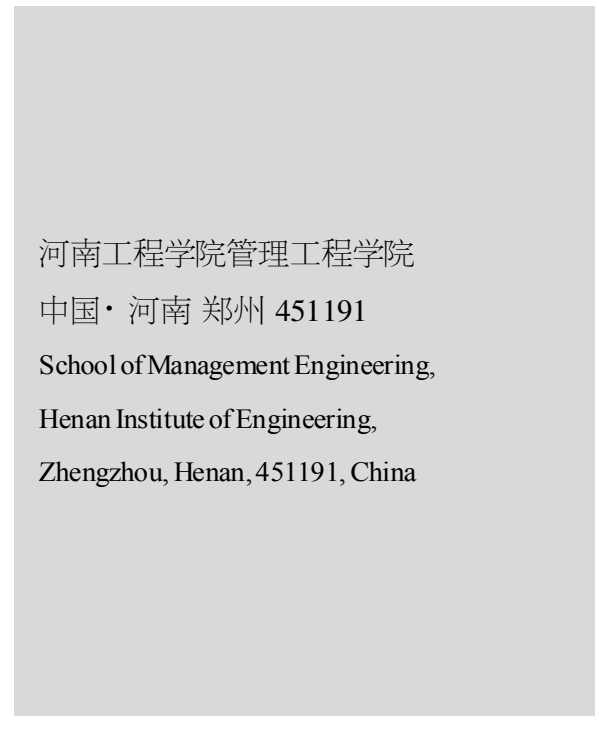

\section{1 引言}

中国工业和服务业之间的比例与相互关系一直是产业经 济研究重点关注的问题之一。尤其是当今中国面临着严峻的 产业升级和结构优化压力, 对于服务业与工业发展之间的研 究和判断显得尤为迫切和必要。

\section{2 研究方法}

采用超效率 DEA 模型可对中国工业与服务业效率进行 计算, 超效率 (Super-Efficiency) 的概念和方法最早是由 Andersen 和 Petersen 等于 1993 年正式提出。超效率的概念与 模型是在数据包络分析 (Data Envelopment Analysis, DEA)方 法基础上提出与发展的, 是对该方法的补充与完善 ${ }^{[1]}$ 。超效率 模型的核心就是将被评价 DMU 从参考集中剔除, 参考其他 DMU 构成的前沿得出效率值, 有效 DMU 的超效率值一般会 大于 1 , 从而可以对有效 DMU 进行区分 ${ }^{[2]}$ 。基于此, 采用超效 率模型。

以中国 31 个省、自治区和直辖市(简称省份, 不含港澳台 地区）工业和服务业便可根据超效率 DEA 的 BCC 模型得到 中国工业各地的纯技术效率 1, 同理可算出中国各地服务业 的纯技术效率 2 , 借鉴李霞 ${ }^{[3]}$ 协调度方法计算反映中国各地工
业与服务业协调发展的综合协调度: $0=\min (1,2) / \max (1,2)$ 。式 中 0 代表工业与服务业协调度。协调度越高, 则表明中国工业 与服务业之间的协调一致程度也越高; 协调度越低, 则表明中 国工业与服务业之间的协调一致程度也越低。

\section{3 中国工业与服务业超效率和协调度分析}

借鉴王建府 ${ }^{[4]}$ 投入产出指标的选取方法, 以 2017 年的中 国各地区的工业和服务业的平均用工人数、资产总计、主营业 务成本做为投入指标; 主营业收入、利润总额做为产出指标, 利用分析软件进行效率指标进行分析。数据均来源于《中国统 计年鉴 2018》和《中国第三产业统计年鉴 2018》。结果整理为 表 1 和图 1 。

表 12017 年中国工业与服务业的超效率值和协调度平均值

\begin{tabular}{c|c|c|c|c|c}
\hline 地 区 & \multicolumn{2}{|c|}{ 工业超效率值 } & \multicolumn{2}{|c|}{ 服务业超效率值 } & 协调度 \\
\hline 东部平均 & 1.034 & $(0.09)$ & 1.294 & $(0.87)$ & 0.727 \\
\hline 中部平均 & 1.002 & $(0.07)$ & 0.776 & $(0.22)$ & 0.772 \\
\hline 西部平均 & 1.028 & $(0.17)$ & 0.991 & $(0.88)$ & 0.7 \\
\hline 全国平均 & 1.023 & $(0.12)$ & 1.043 & $(0.83)$ & 0.728 \\
\hline 最大值 & \multicolumn{2}{|c|}{1.561} & \multicolumn{2}{|c|}{4.46} & 0.971 \\
\hline 最小值 & \multicolumn{2}{|c|}{0.89} & \multicolumn{2}{|c|}{0.383} & 0.224 \\
\hline
\end{tabular}

注: 括号内为变异系数。

由表 1 从超效率值看，中西两部的工业超效率值大于其 


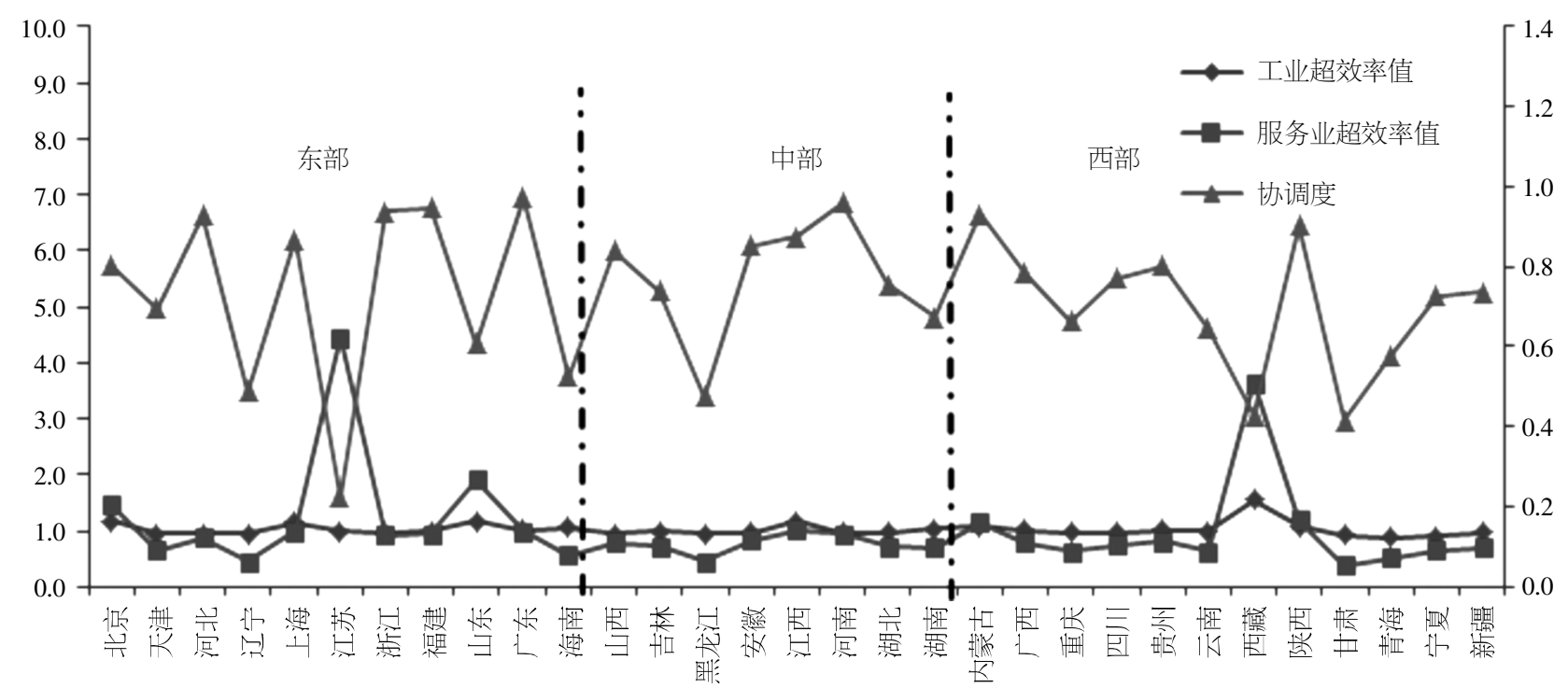

图 12017 年中国各省效率值总体大于各省的服务业超效率值

服务业, 说明中西两部的服务业发展水平滞后于工业发展水 平, 而东部的服务业大于工业超效率值, 说明东部的服务业水 平的发展处于领先水平。中国工业超效率值的最大值为 1.561 , 最小值为 0.890 , 说明中国各部总体的工业水平相差不 大, 而服务业的超效率值最大值为 4.460 , 最小值为 0.383 , 所 以中国各地的服务业发展水平差距较大, 发展不均衡。

从变异系数看, 中国各地区工业变异系数较小, 说明中东 西地区内部的工业水平发展差距较小, 工业发展水平比较均 衡; 而各地区服务业的变异系数较大, 表明各地区内部服务业 发展平衡程度较差, 有较大差异。

从协调度看, 中国各部之间工业与服务业的协调度数值由 大到小次序是:中部、东部、西部。中部的工业与服务业的协调 度最高, 可以看出中部的工业和服务业的发展水平最为接近, 西部的协调度最小, 说明其工业和服务的发展存在较大差距。

由图 1 可以看出东部地区中, 北京、江苏、山东的服务业 的超效率值大于其他工业的超效率值, 尤其是江苏的服务业 水平为全国最高, 与其当地的工业水平差异较大; 中部地区各 省的工业超效率值全都大于服务业超效率值; 西部地区中内 蒙古、西藏、陕西的服务业超效率值大于工业超效率值, 而且 西藏的服务业效率也比较高。

\section{4 讨论}

上述分析表明: 从超效率值看, 中国大多数省份的工业超 效率值大于服务业; 从变异系数看, 工业效率差异小,发展比 较均衡, 而各地区服务业变异系数较大, 发展的均衡程度较差; 从协调度看, 中部的工业与服务业的协调度最高, 东部次之, 西部的协调度最小。

对中国工业与服务业进行协调度分析，对当前中国工业
和服务业的相互关系进行实证研究, 可以看出, 二者之间呈 “工业主导、服务业从属”关系, 即工业自身内循环特征较为明 显, 对服务业的中间需求弱, 依赖程度较低,服务资源对工业 增长的支撑作用尚未充分显现; 服务业增长对工业品投入还 有较高依赖,依靠服务业自身投入获得增长的能力还不显著。 从以上数据可以看出, 东部的工业水平滞后于其服务业水平, 政府应该着重提高其工业水平的发展; 中部的协调度数值较 高, 但其工业水平和服务业水平总体发展不高, 应同时发展和 提高其超效率值; 西部总体的服务业过低, 政府应该加大力 度,缩小其工业和服务业的发展水平。

可以预见, 在未来相当长的时间里, 只要中国国内外需求 环境不发生大的改变, 工业仍将是带动服务业的, 它将主要围 绕工业部门的总量增长与结构升级而展开。然而, 服务业的这 种从属性地位也在发展中不断发生着由量变到质变的改变。 在中短期, 服务业通过创新发展对工业部门优化升级所发挥 的支撑作用将趋于加强; 在长期,服务业与工业在协同、互动 发展基础上的产业界限逐渐模糊, 融合发展在更广范围、更大 程度上成为现实。

\section{参考文献}

[1]孔阳, 潭江涛.基于超效率 DEA 的西部地区工业生态效率评价 [J].价值工程,2018(13):67-70.

[2]张恒,周中林,郑军.长江三角洲城市群科技服务业效率评价— 基于超效率 DEA 模型及视窗分析[].科技进步与对策,2019,36(5):46-53.

[3]李霞.基于数据包络分析的我国流通经济与消费协调性评价 [J].商业经济研究,2013(36):44-45.

[4]王建府.我国区域经济发展的成本效率分析 [J].中南民族大学 学报(人文社会科学版),2018,38(3):166-169. 